\title{
Air Pollutants and Attention Deficit Hyperactivity Disorder Medication Administration in Elementary Schools
}

\author{
Rami Saadeh ${ }^{1}$, Wasantha Jayawardene ${ }^{2}$, David Lohrmann ${ }^{2}$, and Ahmed YoussefAgha ${ }^{2}$ \\ ${ }^{1}$ Jordan University of Science and Technology \\ ${ }^{2}$ Indiana University Bloomington
}

November 15, 2020

\begin{abstract}
Introduction. Air pollution is considered a risk factor for several diseases, including respiratory and cardiovascular. However, the effects of air pollution on neurobehavioral disorders is not confirmed yet. Thus, this study aimed at determining the association of seven air pollutants with ADHD medication administration (ADHD-MA) in Pennsylvania-located elementary schools over a three-year period. Methods. An ecological study design involving records of 168,825 children from elementary schools in 49 Pennsylvania counties was used. The number of children with ADHD-MA was extracted from an online software specifically designed for allowing nurses to record health conditions in schools. Daily measurements of air pollutants were gained from the U.S Environmental Protection Agency. Results. The mean number of ADHD-MA significantly increased over the 3-year period [163.9 (+ 70.1) in 2008, $317.2(+84.4)$ in 2009, and $427(+101.4)$ in 2010]. The difference in the number of ADHD-MA among the three years and among the four seasons, for all years, were statistically significant $(\mathrm{P}<0.001)$. Three air pollutants (SO2, CO, and PM2.5) were significantly associated with ADHD-MA; no interactions among air pollutants were significant. Conclusion. Air pollution is likely associated with both ADHD incidence and ADHD-MA. Prospective epidemiological and biomedical studies could examine the relationship between air pollution and ADHD symptoms.
\end{abstract}

\section{Hosted file}

Int J of Clinical Practice.pdf available at https://authorea.com/users/372461/articles/ 493053-air-pollutants-and-attention-deficit-hyperactivity-disorder-medicationadministration-in-elementary-schools

\section{Hosted file}

Figure 1.pdf available at https://authorea.com/users/372461/articles/493053-air-pollutantsand-attention-deficit-hyperactivity-disorder-medication-administration-in-elementaryschools

\section{Hosted file}

Table 1 updated.pdf available at https://authorea.com/users/372461/articles/493053-airpollutants-and-attention-deficit-hyperactivity-disorder-medication-administration-inelementary-schools

\section{Hosted file}

Table 2 updated.pdf available at https://authorea.com/users/372461/articles/493053-airpollutants-and-attention-deficit-hyperactivity-disorder-medication-administration-inelementary-schools

\section{Hosted file}


Table 3 updated.pdf available at https://authorea.com/users/372461/articles/493053-airpollutants-and-attention-deficit-hyperactivity-disorder-medication-administration-inelementary-schools 